\title{
Effect of Initial On-Site Curing on 28-Day Cylinder Strength
}

\author{
by José Calavera, Jaime Fernández-Gómez, Germán González, Jorge Ley, and Pedro López
}

The initial curing of concrete specimens for quality assurance is addressed in different ways in testing standards, which often specify requirements that are diffcult to meet in practice unless very costly initial curing chambers are available. The failure to meet these requirements in many areas of the world does not appear to result in adverse convequences. This study analyzed six initial curing temperature schemes, all with cycles similar to natural conditions to avoid the simplificatons interent in constant temperature curing. Three strengths of concrete and two intial curing tintes (24 and 72 hours) were used in this siudy.

The findings showed that initial curing time had no effect on 28 -day strength. The 28-day strength also proved to be resilient to naximum and minimunt intial curitg temperatures ouside the limits stated in the standards considered in this study.

Keywords compressive strength; concrete specinens; initial curing.

\section{INTRODUCTION}

The initial on-site curing of concrete specimens for quality assurance has always been a controversial issue in the relations among concrete suppliers, builders, and control laboratories. The standards in place establish conditions that are difficult to meet in practice in many parts of the world, and the limitation of specimen on-site curing time to 24 or 48 hours generates logistical problems during weekends.

Ensuring a minimum temperature of 16 to $20^{\circ} \mathrm{C}(60$ to $68^{\circ} \mathrm{F}$ ) is fairly simple and inexpensive-all it takes is an electric heater fitted with a thermostat. In countries or areas where summertime temperatures are high, however, the solutions to the problem of not exceeding $27^{\circ} \mathrm{C}\left(80^{\circ} \mathrm{F}\right)$ can be complex and costly. In fact, in most countries, the vast majority of work sites fail to comply with on-site curing requirements. Nevertheless, reports on the negative effects on 28-day strength do not seem common.

Three standards that regulate the conditions for making and curing concrete specimens on site are discussed as follows:

- ASTM C31/C31M-09' requires keeping specimens in molds on site for no more than 48 hours with a surrounding air temperature from 16 to $27^{\circ} \mathrm{C}(60$ to $80^{\circ} \mathrm{F}$ ) for concretes with a strength of under $40 \mathrm{MPa}$ (6000 psi) and from 20 to $26^{\circ} \mathrm{C}\left(68\right.$ to $78^{\circ} \mathrm{F}$ ) for higher-strength concretes.

- EN 12390-2:2009, Section 5.5.1., ${ }^{2}$ stipulates that specimens must be kept in their molds for at least 16 hours but no more than 3 days, protected from impact, vibrations, and dehydration at a storage temperature of $20 \pm 5^{\circ} \mathrm{C}(68 \pm$ $\left.9^{\circ} \mathrm{F}\right)$ or $25 \pm 5^{\circ} \mathrm{C}\left(77 \pm 9^{\circ} \mathrm{F}\right)$ in warm climates.

- EHE- $08^{3}$ specifies other conditions. Table 1 summarizes the requirements in this standard.

Because fresh concrete specimens should not be transported before final setting (as the resulting "revibration" might enhance strength), some standards state that specimens should remain on site for 24 hours. This is particularly onerous in linear works such as roads and railways, which tend to involve works requiring sampling of structural concrete every
$0.8 \mathrm{~km}(0.5$ miles). This calls for a fair number of on-site curing chambers.

Such strict conditions render quality assurance difficult. EHE-08 and ASTM C3L/C3LM-09' require different conditions depending on concrete strength. EHE- $08^{3}$ mandates a maximum of 24 hours on site if the concrete strength is greater than or equal to $35 \mathrm{MPa}$ (5000 psi), whereas ASTM C31/C $31 \mathrm{M}-09^{\mathrm{k}}$ calls for a narrower temperature range $\left(20\right.$ to $26^{\circ} \mathrm{C}\left[68\right.$ to $\left.\left.78^{\circ} \mathrm{F}\right]\right)$ and a specified strength of $40 \mathrm{MPa}(5000 \mathrm{psi})$ or greater. Consequently, the use of climatic chambers with fairly precise temperature control is required under extreme ambient temperatures. The latter standard limits the onsite slorage time to 48 hours for all specimens, with the aforementioned concomitant weekend collection problems. EN $12390-2: 2009^{2}$ draws no distinction between different concrete strengths and allows for longer on-site curing periods, thereby solving these two major difficulties.

\section{RESEARCH SIGNIFICANCE}

Prior research ${ }^{4-6}$ has shown the effects of on-site storage time withir the 24- to 72-hour range on the strength of the concretes studied. The initial curing temperature was constant throughout the storage period in these studies. For temperatures up to $30^{\circ} \mathrm{C}\left(86^{\circ} \mathrm{F}\right)$, the decline in 28 -day strength did not exceed $7 \%$ in any of the specimens, whereas much more unfavorable and clearly unacceptable results were obtained for initial temperatures of $40^{\circ} \mathrm{C}\left(104^{\circ} \mathrm{F}\right)$. Low initial temperatures proved to have a lesser effect than expected. The findings showed that the lower initial curing temperature limits established in the standards (adopting the mean of the three, $15^{\circ} \mathrm{C}\left[59^{\circ} \mathrm{F}\right]$ ) can be reduced without consequences on 28-day strength.

All of these experiments were conducted under conditions that prevented specimen drying, pursuant to Note 6 in ASTM C31/C31M-09. ${ }^{1}$

One area that has not been studied systematically to date is initial on-site curing under cyclic temperature conditions

Table 1-Initial curing conditions given in EHE- $08^{3}$

\begin{tabular}{c|c|c}
\hline$f_{c k}, \mathrm{MPa}(\mathrm{psi})$ & $\begin{array}{c}\text { Temperature range, } \\
{ }^{\circ} \mathrm{C}\left({ }^{\circ} \mathrm{F}\right)\end{array}$ & $\begin{array}{c}\text { Maximum on-site storage time, } \\
\text { hours }\end{array}$ \\
\cline { 1 - 1 }$<35(5000)$ & \multirow{2}{*}{15 to $30(59$ to 86$)$} & 72 \\
\cline { 1 - 1 }$\geq 35(5000)$ & & 24 \\
\hline All strengths & 15 to $35(59$ to 95$)$ & 24 \\
\hline
\end{tabular}


José Calavera, FACl, is Professor Emeritus in the Faculty of Civil Engineering at the Polytechnic University of Madrid, Madrid, Spain, and Honorary President of the Instituto Técnico de Materiales y Construcciones (INTEMAC)

ACI member Jaime Fernández-Gómez is a Full Professor in the Building and Precasting Department in the Faculty of Civil Engineering at the Polytechnic University of Madrid and Head of the INTEMAC Laboratory.

Germán González is Head of the Materials Testing Department at the INTEMAC Laboratory. His research interests include concrete properties.

Jorge Ley is an Associate Professor in the Building and Precasting Department in the Faculty of Civil Engineering at the Polytechnic University of Madrid and Head of the Structural Testing Department at the INTEMAC Laboratorv. His research interests include bridge rehabilitation and strengthening.

Pedro López is Head of the Material Chemical Analysis Department at the INTEMAC Laboratory. His research interests include the properties of cement and other cementitious materials.

representative of the real conditions prevailing in a given climate. The tendency has been to use the maximum daily temperature as the constant curing temperature in research, studying summer conditions and analogously studying the minimum daily temperature for researching winter conditions. This appears to be overly conservative.

This study analyzed the effect of the two aforementioned factors, which impose restrictive quality assurance requirements-on-site storage time and decline in strength - using real thermal cycles representative of a continental climate. The research conducted is described in the following.

\section{Concrete strength}

\section{TEST VARIABLES}

The three specified concrete strengths used were 25,50 , and $80 \mathrm{MPa}(3600,7200$, and 11,600 psi). The constituents and mixture proportions are given in Table 2 .

The concretes were prepared at INTEMAC's Central Laboratory in Madrid, Spain, in accordance with the applicable requirements given in ASTM C192/ C192M-07. ${ }^{7}$

\section{Initial curing conditions}

Immediately after the concretes were prepared (as described in the following), the molded specimens were covered with moist burlap and placed in sealed plastic bags (an extension of the procedure developed and normally implemented at INTEMAC). They were then placed in the laboratory's climatic chamber, which was programmed to provide the conditions set out in the test, namely temperatures ranging from -5 to $40^{\circ} \mathrm{C}\left(23\right.$ to $\left.104^{\circ} \mathrm{F}\right)$ and a maximum deviation of $\pm 0.5^{\circ} \mathrm{C}\left( \pm 1^{\circ} \mathrm{F}\right)$. The moisture retention procedure and climatic chamber are shown in Fig. 1 to 3 .

Table 2-Concrete mixture proportions for this study

\begin{tabular}{|c|c|c|c|}
\hline \multirow[b]{2}{*}{ Constituent material } & \multicolumn{3}{|c|}{ Quantity, $\mathrm{kg} / \mathrm{m}^{3}$} \\
\hline & $25 \mathrm{MPa}$ (3600 psi) & $50 \mathrm{MPa}$ (7200 psi) & $80 \mathrm{MPa}(11,600 \mathrm{psi})$ \\
\hline Siliceous gravel $4 / 16$ & 1023 & 981 & 1045 \\
\hline River sand $0 / 4$ & 934 & 895 & 800 \\
\hline CEM II/A-M 42.5 R & 270 & 360 & - \\
\hline CEM I $52.5 \mathrm{R}$ & - & - & 400 \\
\hline Water & 160 & 152 & 139 \\
\hline Multi-purpose admixture & 2.2 & 2.8 & 3.71 \\
\hline High-range water-reducing admixture & - & 2.80 & 8.35 \\
\hline Silica fume & - & - & 32 \\
\hline
\end{tabular}

Note: $1 \mathrm{~kg} / \mathrm{m}^{3}=1.686 \mathrm{lb} / \mathrm{yd}^{3}$

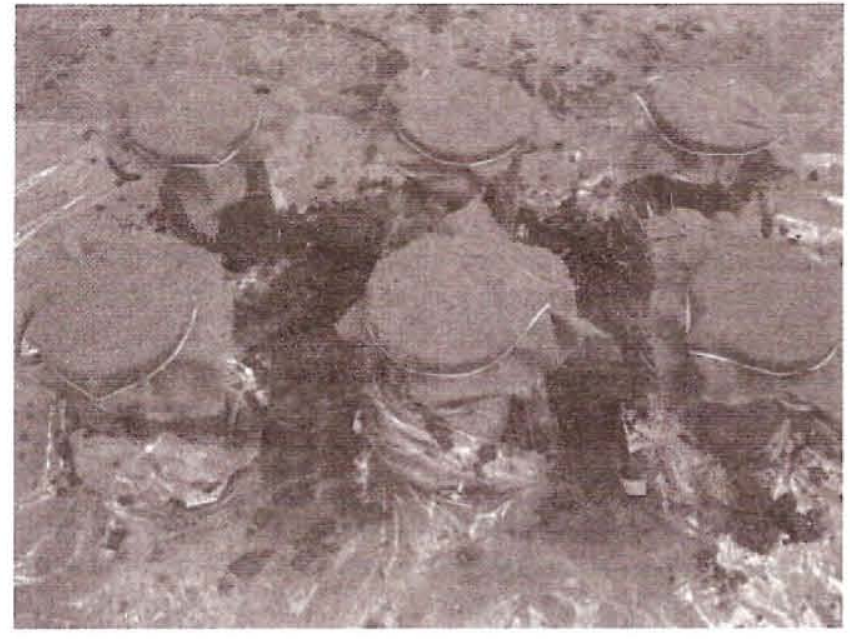

Fig. 1-Protecting specimens against moisture loss by applying moist burlap.

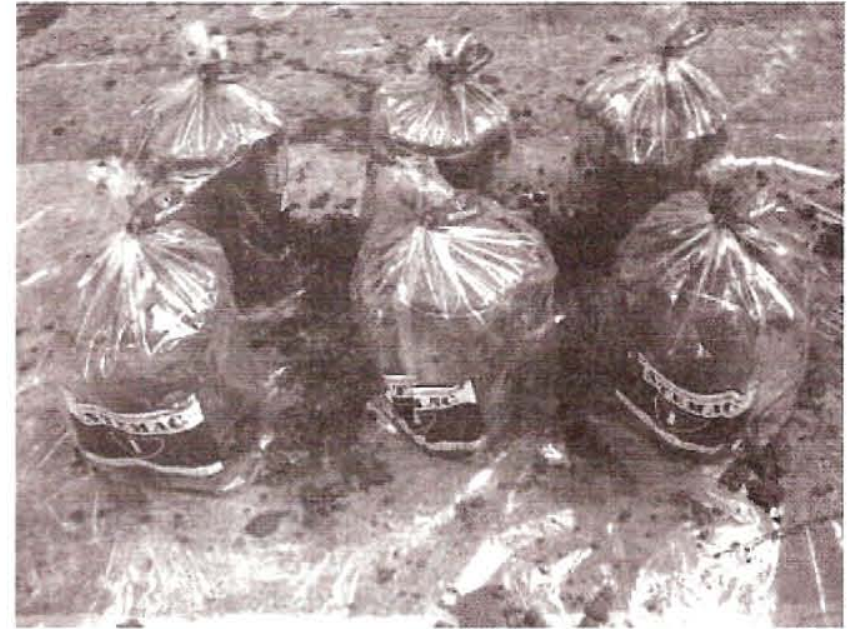

Fig. 2-Protecting specimens against moisture loss by use of sealed bags. 


\section{Storage in climatic chamber}

Storage times of 24 and 72 hours were used, which correspond to the maximum times specified in EHE- $08^{3}$ (refer to Table 1). These are also the overall upper and lower limits for on-site curing given in the standards discussed herein.

\section{Initial thermal curing cycles}

In most experimental work conducted on this subject, the curing temperature is kept constant throughout the initial curing period. This does not represent the conditions to

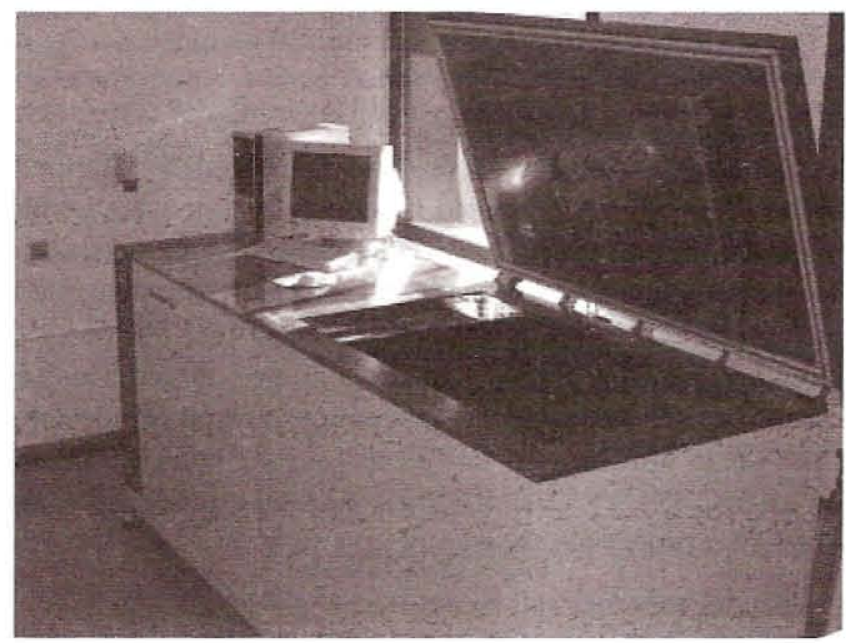

Fig. 3-Climatic chamber used.

Cycle $1: 22^{\circ} \mathrm{C}$ to $40^{\circ} \mathrm{C}\left(72{ }^{\circ} \mathrm{F}\right.$ to $\left.104^{\circ} \mathrm{F}\right)$

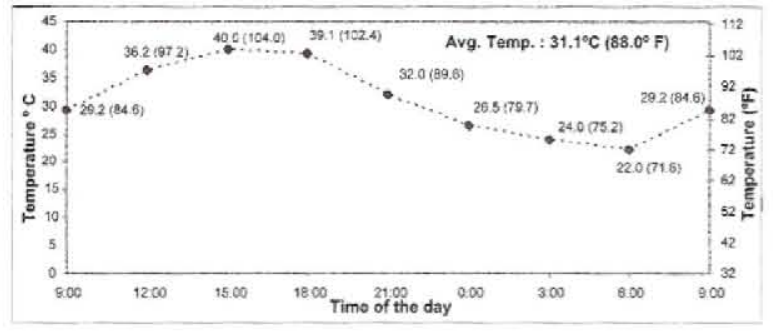

Cycle $3: 15^{\circ} \mathrm{C}$ to $30^{\circ} \mathrm{C}\left(59^{\circ} \mathrm{F}\right.$ to $\left.86^{\circ} \mathrm{F}\right)$

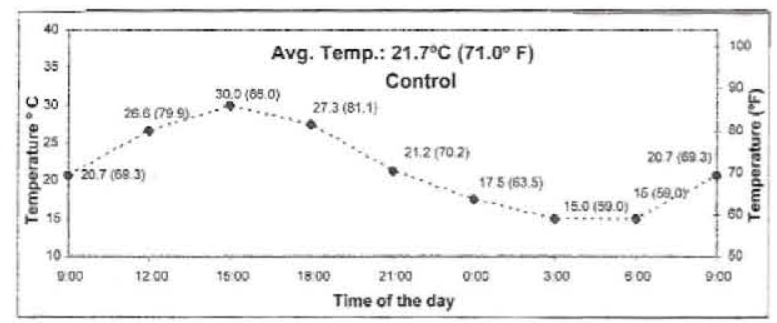

Cycle 5: 0 to $10^{\circ} \mathrm{C}\left(32^{\circ} \mathrm{F}\right.$ to $\left.50^{\circ} \mathrm{F}\right)$

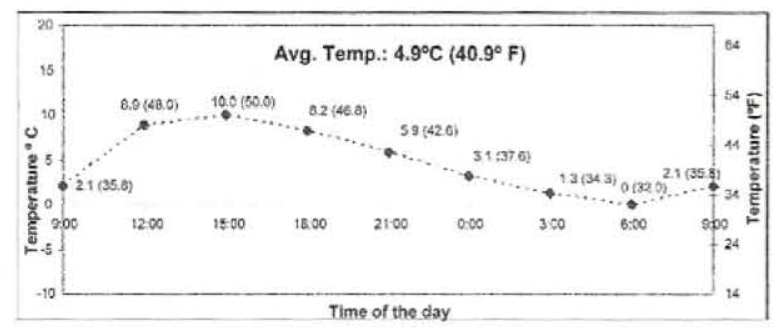

which specimens are actually exposed during initial on-site curing, in which the daily thermal cycle varies considerably. Therefore, laboratory curing at a constant mean temperature may not provide realistic results.

Consequently, one control and five experimental thermal cycles were used for initial curing, with daily temperatures ranging between the values shown in the following:

- Cycle $1: 22$ to $40^{\circ} \mathrm{C}\left(72\right.$ to $\left.104^{\circ} \mathrm{F}\right)$ (extreme);

- Cycle 2: 18 to $35^{\circ} \mathrm{C}\left(64\right.$ to $\left.95^{\circ} \mathrm{F}\right)$;

- Cycle 3: 15 to $30^{\circ} \mathrm{C}\left(59\right.$ to $86^{\circ} \mathrm{F}$ ) (control);

- Cycle $4: 9$ to $20^{\circ} \mathrm{C}\left(48\right.$ to $\left.68^{\circ} \mathrm{F}\right)$;

- Cycle 5: 0 to $10^{\circ} \mathrm{C}\left(32\right.$ to $\left.50^{\circ} \mathrm{F}\right)$; and

- Cycle 6: -5 to $3^{\circ} \mathrm{C}\left(23\right.$ to $\left.37^{\circ} \mathrm{F}\right)$ (extreme).

These values were deduced from a 20 -year statistical study of extreme dry bulb temperatures in Madrid, Spain. Assembled by the Asociación Técnica Española en Climatización y Refrigeración (ATECYR) (the Spanish technical association for HVAC), ${ }^{8}$ the database gives the 20-year mean high and low temperatures and standard deviations for each 3-hour interval throughout the year.

Cycles 1 and 6 constitute the 10\% quantile for the two warmest and coldest months, respectively. Cycles 2, 5, and 4 represent the mean likely values in the warmest, coldest, and most temperate months, respectively. Finally, the temperature range defined in Cycle 3 - that is, 15 to $30^{\circ} \mathrm{C}$ ( 59 to $86^{\circ} \mathrm{F}$ ) (the limits set out in EN $12390-2: 2009^{2}$ ) —was used as a reference condition. The six 24-hour cycles are represented in Fig. 4.

Madrid has a continental climate with cold (although not extremely cold) winters, hot summers, and low relative humidity.

Cycle 2: $18^{\circ} \mathrm{C}$ to $35^{\circ} \mathrm{C}\left(64^{\circ} \mathrm{F}\right.$ to $\left.95^{\circ} \mathrm{F}\right)$

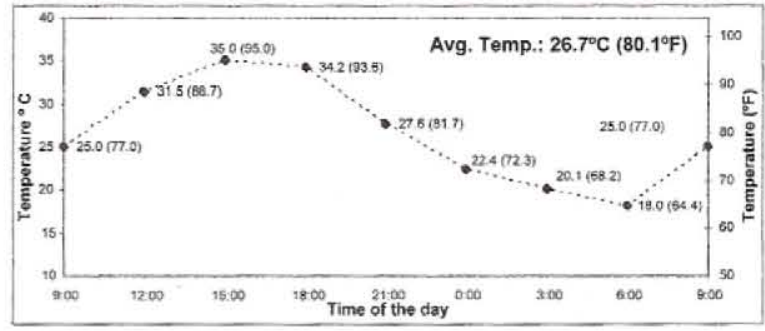

Cycle $4: 9^{\circ} \mathrm{C}$ to $20^{\circ} \mathrm{C}\left(48^{\circ} \mathrm{F}\right.$ to $\left.68^{\circ} \mathrm{F}\right)$

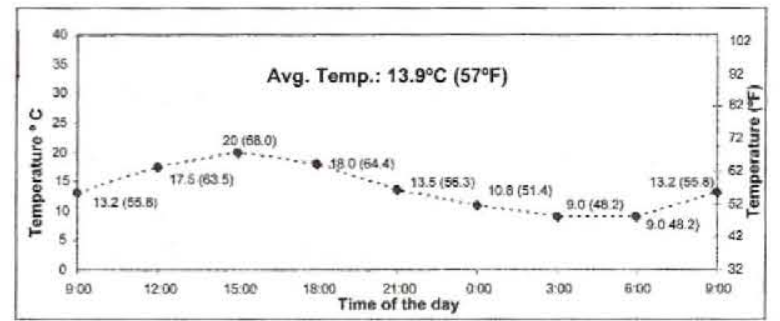

Cycle $6:-5^{\circ} \mathrm{C}$ to $3{ }^{\circ} \mathrm{C}\left(23^{\circ} \mathrm{F}\right.$ to $\left.37^{\circ} \mathrm{F}\right)$

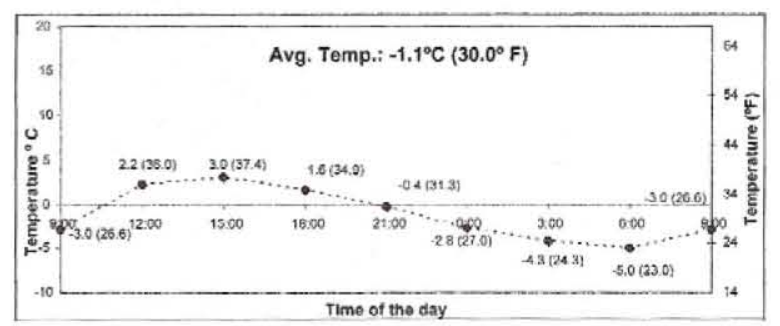

Fig. 4-Thermal cycles applied during 24-hour initial curing. 
Table 3-Compressive strength results for different curing conditions

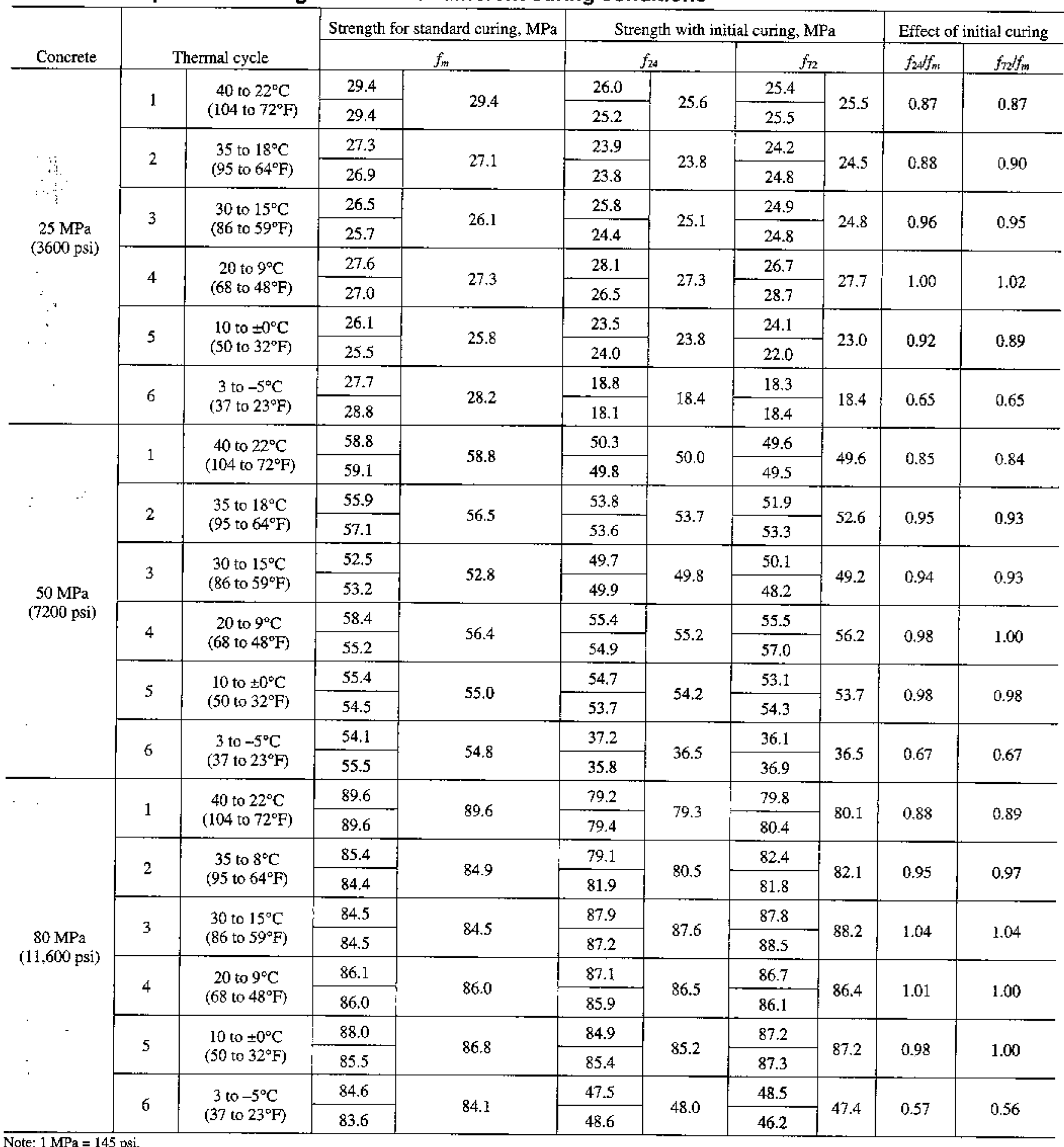

Note: $1 \mathrm{MPa}=145$ psi.

These are perhaps the harshest conditions to which concrete specimens may be exposed during initial curing.

The specimens stored for 72 hours were exposed to three consecutive cycles, each identical to the 24-hour cycles defined previously.

\section{TESTS CONDUCTED}

A $0.15 \mathrm{~m}^{3}\left(0.20 \mathrm{yd}^{3}\right)$ batch of concrete was prepared for each test condition using a $0.35 \mathrm{~m}^{3}\left(0.20 \mathrm{yd}^{3}\right)$ countexcurrent, vertical shaft planetary mixer. Six cylindrical specimens measuring $150 \times 300 \mathrm{~mm}(6 \times 12$ in.) were molded for 28 -day compression testing as follows:

- Two specimens for initial curing in the climatic chamber for 24 hours;

- Two specimens for initial curing in the climatic chamber for 72 hours; and

- Two reference specimens for initial curing in a chamber at standard temperature $\left(20 \pm 2^{\circ} \mathrm{C}\left[68 \pm 4^{\circ} \mathrm{F}\right]\right)$.

The specimens were tested as specified in EN 12390-3: $2009^{9}$ and capped with high-strength sulfur mortar pursuant to ASTM C617-09.10

\section{EXPERIMENTAL RESULTS}

Table 3 gives the 28-day strength results for the two specimens and the mean value for each curing condition. The effect of initial curing was analyzed by dividing 


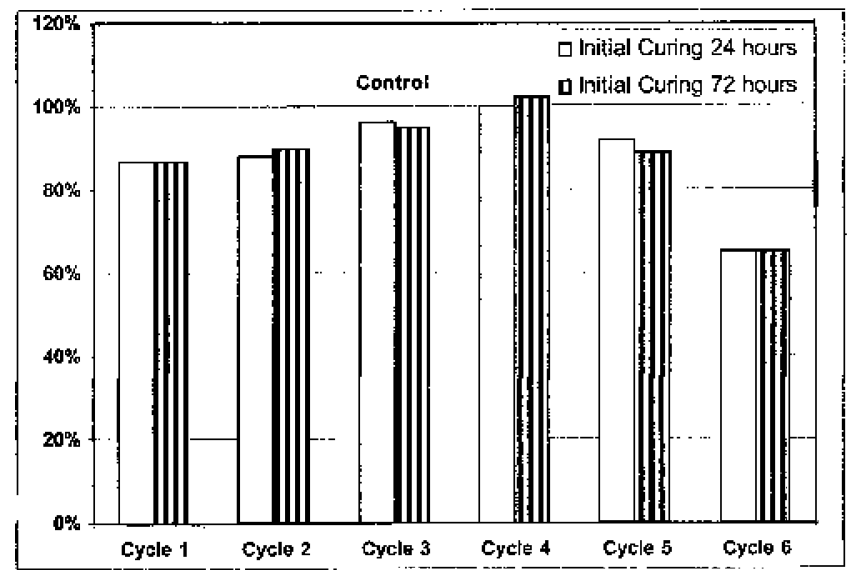

(a) $25-\mathrm{MPa}(3600-\mathrm{psi})$ concrete

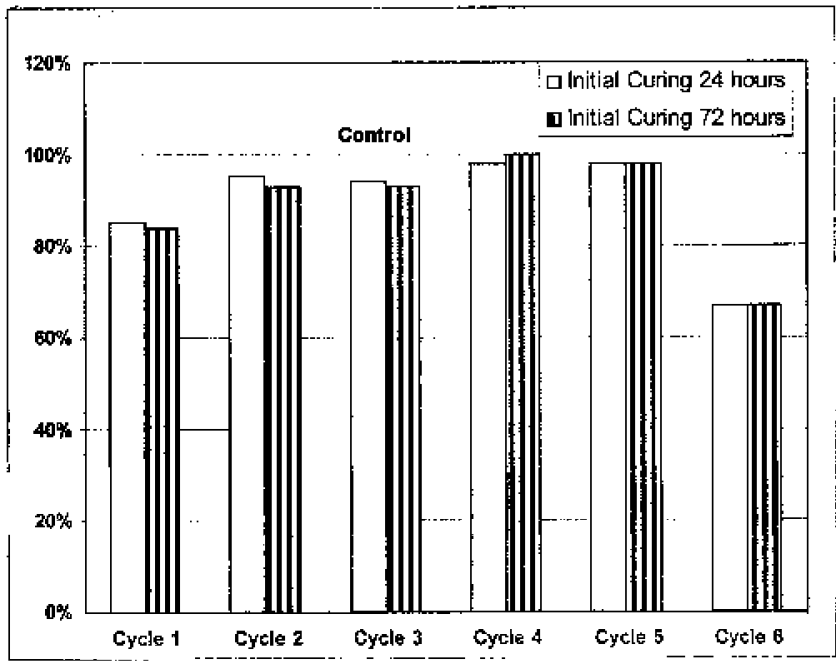

(b) $50-\mathrm{MPa}(7200-\mathrm{psi})$ concrete

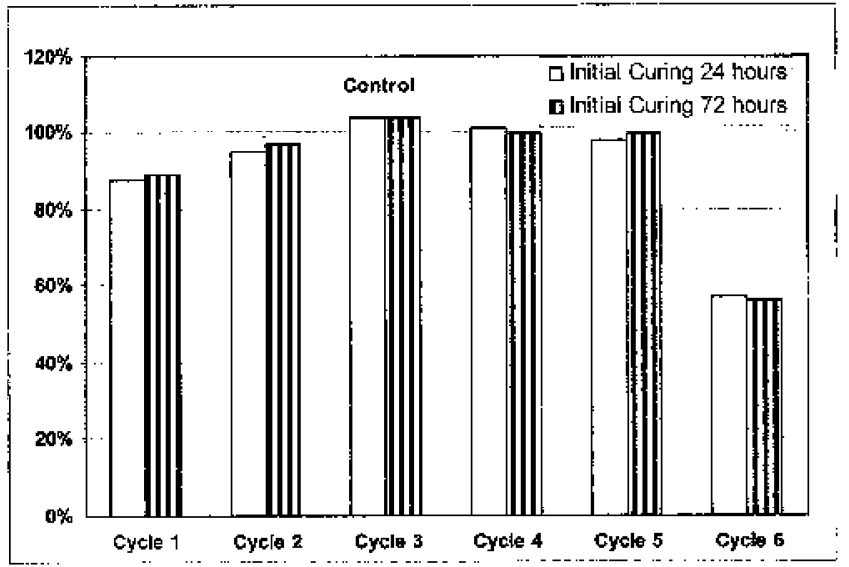

(c) 80-MPa (11600-psi) concrete

Fig. 5-Twenty-eight-day compressive strength relative to standard curing for each type of concrete.

the average strength values for the specimens cured for 24 and 72 hours at the cyclic temperatures by the average strength for the respective specimens cured at the standard temperature.

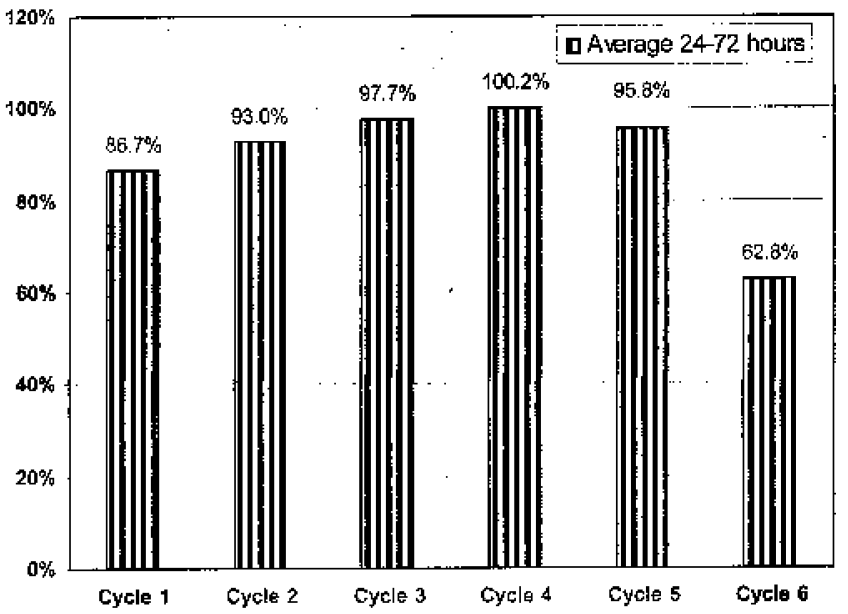

Fig. 6 - Average 28-day strength relative to standard curing for all concrete combined.

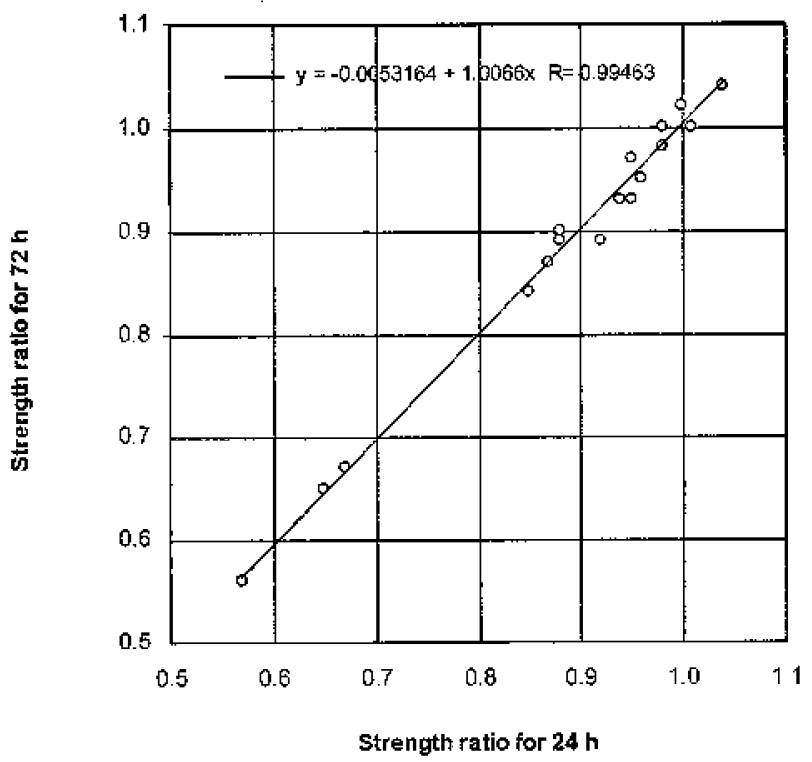

Fig. 7-Correlation between 24-and 72-hour strength ratio for all cycles and types of concrete.

The findings for each type of concrete tested are shown as bar graphs in Fig. 5. Figure 6 shows the mean value percentages for all the concretes combined.

No significant difference was observed between the results for the two on-site storage times for initial curing. This can be seen in Fig. 7, which shows that the best fit between the strength ratio for 24 and 72 hours of initial curing is a straight line passing through the origin and with a slope equal to approximately 1.0 . The maximum differences detected for the $25 \mathrm{MPa}$ ( $3600 \mathrm{psi}$ ) concrete were 10 greater than 3.1 percentage points. Requiring shorter on-site storage for higher-strength concrete would not appear to be justified.

Given that the values for the two initial curing times are nearly identical, the mean value was used to represent the effect of the curing cycle. Figure 8 shows the average strength ratios for the various cyclic temperatures plotted against the concrete compressive strength.

The curing cycle also appeared to have a greater impact on 28-day strength in the $25 \mathrm{MPa}$ (3600 psi) concrete. The decline in mean strength observed in the 50 and $80 \mathrm{MPa}$ (7200 and 11,600 psi) concretes for the four thermal cycles 


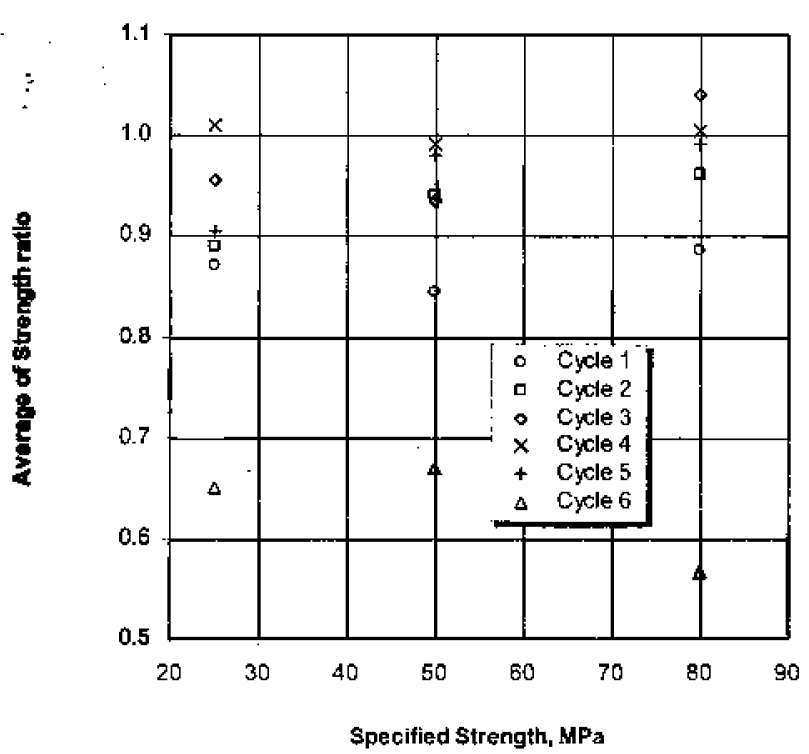

Fig. 8-Mean value of strength ratio for all cycles plotted against nominal concrete compressive strength. (Note: l $\mathrm{MPa}=145 \mathrm{psi}$ )

(Cycles 2 to 5), whose overall extreme temperatures were 35 and $0^{\circ} \mathrm{C}\left(95\right.$ and $32^{\circ} \mathrm{F}$ ), did not exced 5.9 percentage points. The maximum decline recorded for the $25 \mathrm{MPa}$ (3600 psi) concrete, in tum, was 10.9 percentage points. Therefore, the more demanding initial curing temperature conditions imposed by ASTM C31/C31M-09' for higherstrength concrete do not appear to be justified.

The average reduction in strength was no greater than 7 percentage points for any of the concretes, except in the two extreme cycles (Cycles 1 and 6). For Cycles 2 to 5 , the average reductions were 6,4 , and 0 percentage points for the 25,50 , and $80 \mathrm{MPa}(3600,7200$, and $11,600 \mathrm{psi})$ concretes, respectively. These results show that the effect of the initial curing history declines with rising concrete strength. The lower water-cement ratios $(w / c)$ contribute to the quicker development of early strength and microstructure during initial curing. In all likclihood, this reduces the effects of the initial curing temperature.

Thermal cycles involving maximum temperatures of over $30^{\circ} \mathrm{C}\left(86^{\circ} \mathrm{F}\right)$ may be acceptable; even at $35^{\circ} \mathrm{C}\left(95^{\circ} \mathrm{F}\right)$, the values obtained for the stronger concretes were within 5 percentage points of the control values. The small effect of temperature during initial curing was even more striking for low temperatures. The specimens exposed to Cycle 4 , whose lower limit was noncompliant with all the standards cited, exhibited the same strength values as the controls.

\section{CONCLUSIONS}

This study explored the effect of initial curing variables on the 28-day strength of concrete specimens made at the work site. As opposed to previous studies, cyclic temperatures were used during initial curing to provide a better representation of on-site conditions.

Based on the findings described previously, the following conclusions can be drawn:
- In specimens made with 25 to $80 \mathrm{MPa}$ (3600 to $11,600 \mathrm{psi}$ ) concrete, no significant difference was detected between the initial curing durations of 24 and 72 hours, even under the least favorable temperature conditions. This lends support to the provisions of EN $12390-2 \cdot 2009^{2}$ which specify a maximum 72 -hour initial curing period in all cases. The provisions of standards that call for shorter maximum on-site curing are not justified and are a source of logistical problems with respect to the collection of specimens made on a Friday or the day before a holiday.

- No differences were found between the results obtained for the three categories of concrete tested that would justify the provisions in ASTM C $31 / \mathrm{C} 31 \mathrm{M}-09^{1}$ and EHE-08 $8^{3}$ that vary the initial curing conditions on the basis of strength. On the contrary, the results indicated that higher-strength concrete may be less affected by a high initial curing temperature. The present findings also corroborated the EN 12390-2:2009² approach, in which no strength-based distinctions are drawn.

- The ranges of temperatures permitted in the standards are overly narrow. Even the temperature range prescribed in EN $12390-2: 2009^{2}$-namely, 15 to $30^{\circ} \mathrm{C}(59$ to $86^{\circ} \mathrm{F}$ )-can be exceeded slightly on the higher end and moderately on the lower end with no perceptible effect on 28-day strength.

- Further research is required to confirm these findings for other cementitious systems.

\section{REFERENCES}

1. ASTM C31/C31M-09, "Standard Practice for Making and Curing Concrete Test Specimens in the Field," ASTM Intemational, West Conshohocken, PA, 2009, 6 PP

2. EN 12390-2:2009, "Testing Hardened Concrete-Par 2: Making and Cunng Specimens for Strength Tests," CEN, Brussels, Belgium, 2009 , $12 \mathrm{pp}$.

3. EHE-08. "Instrucción de Hornigón Estructural," Chapter 16, Ministerio de Fonento, Madrid, Spain, 2008.

4. Calavera, J.; Fernández Gómez, J.; González Isabel, G,; and Ley, J, "Estudio Lxperimental sobre la Influencia de Distintos Procedimientos de Curado fricial en Obra. en la Resistencia a Compresión de Probetas de Hormigón." Notas de Información Técnica NTT 1-05, DNTEMAC, Nov. 2005. $29 \mathrm{pp}$.

5. Fernández, J.. "Estudio Experimental dc la Influcncia de las Condiciones de Curado Inicial en la Resistencia de Probetas Moldeadas de Hotmigón," Hormigón y Acero, V. 164, No. 3, 1987. pp. 129-145.

6. Meininger. R. C. "Effects of Initial Field Curing on Standard 28-Day Cylinder Strengths;" Cenent, Concrete and Aggregates, V. 5, No, 2, Jan. 1983, pp. 137-141.

7. ASTM C192/C192M-07, "Standard Practice for Making and Curing Concrete Test Specimens in the Laboratory," ASTM Intcrnational, West Conshohocken, PA. 2007, 8 pp.

8. Comitć Científico de ATECYR, "Datos Climáticos de Madrid," ATECYR-CENTRO, Madrid, Spain, 1996.

9. EN 12390-3:2009, "Testing Hardened Concrete-Part 3: Compressive Strength of Test Specinucns," CEN, Btussels, Belgium, 2009, $22 \mathrm{pp}$.

10. ASTM C617-09, "Standard Practice for Capping Cylindrical Concrete Specimens," ASTM International, West Conshohocken, PA, 2009, 5 pp. 